\title{
En mann i 40-årene med flere krampeanfall
}

\author{
En mann i 40-årene hadde de siste 15 årene gjentatte ganger vært \\ innlagt til utredning ved nevrologiske avdelinger og spesialiserte \\ epilepsisykehus - alle med konklusjonen psykogene, ikke-epileptiske \\ krampeanfall (psychogenic non-epileptic seizure - PNES), men uten \\ forslag til behandling. Han hadde frem til aktuelle behandling også \\ flere ganger vært utredet psykiatrisk, hvor krampeanfallene ble opp- \\ fattet som dissosiative og forenlige med psykogene ikke-epileptiske \\ krampeanfall. Psykoterapeutiske og medikamentelle tilnærminger \\ hadde ikke vært effektive.
}

\begin{abstract}
Pasienten hadde sitt første anfall i forbindelse med høy feber under en feriereise. Anfallet besto i tap av bevissthet og atypiske kramper. Han ble utredet på sykehus, også av nevrolog, uten at man fant tegn til patologiske hjerneorganiske endringer. Man mente at et forøkt alkoholforbruk $i$ ferien i kombinasjon med høy feber kunne ha vært utløsende faktorer. De neste seks årene hadde han to liknende anfall $i$ forbindelse med luftveisinfeksjon og feber
\end{abstract}

Det er kjent at alkohol kan utløse anfall, forverre anfallskontroll hos epilepsipasienter eller indusere epilepsi. Hver tredje pasient som innlegges akutt etter et epileptisk anfall, har hatt et forhøyet alkoholforbruk i tiden før anfallet (1). Feberutløste anfall er også vanlige, men oftere hos barn. Disse forårsaker som regel ingen hjerneskader (2).

Åtte år etter det første anfallet fikk han tilbakevendende anfall som startet med ufrivillige bevegelser, mest i ekstremitetene, ved full bevissthet og ledsaget av hyperventilering. Bevegelsene ble etterfulgt av bevissthetstap uten ufrivillig avgang av urin eller avføring og med amnesi for krampeperioden. Krampene kunne vare fra få til 40 minutter, også $i$ serier som kunne pågå over flere timer. Noen dager kunne være uten anfall, mens han andre dager kunne ha flere. Til sammen hadde han gjennomsnittlig 6-30 anfall per måned. Anfallene ble fremprovosert av jobbrelatert stress, søvnløshet og isituasjoner med mange tilstedeværende mennesker og støy. Etter anfallene var han vanligvis søvnig og sliten, med smerter i rygg og knær som kunne vare i flere dager.

Etter ytterligere tre år fikk han tiltakende vanskeligheter med å finne ord på gjenstander. Han opplevde også at han på «dårlige dager», forut for nye anfall, ble mer langsom både $i$ tale og bevegelser.
I løpet av disse årene var han gjentatte ganger innlagt i nevrologisk avdeling til utredning med blant annet spinalpunksjon, EEG og MR caput. Det ble ikke gjort funn som kunne forklare tilstanden. EEG ble fortolket som lett patologisk med lett økt innslag av langsom aktivitet over venstre frontotemporalregion, men uten sikker epileptisk aktivitet. Konklusjonen var psykogene, ikke-epileptiske krampeanfall. Bortsett fra escitalopram og diazepam, som ikke hadde merkbar effekt, fikk han ingen medikamentell behandling.

Psykogene, ikke-epileptiske krampeanfall kan defineres som en observerbar plutselig anfallsaktig forandring $i$ atferd eller bevissthet som likner epileptiske anfall, men som ikke er ledsaget av de EEG-forandringer som er karakteristiske for epileptiske anfall eller av annen evidens for epilepsi eller annen somatisk årsak til anfallene. Imidlertid vil pasienter som innlegges akutt med store dramatiske GTK-liknende anfall, og hvor psykiatriske undersøkelse ikke avdekker psykisk lidelse, etter manges mening kunne klassifiseres til å ha konversjon/ dissosiasjon, slik at anfallene klassifiseres som dissosiative/psykogene, ikke-epileptiske krampeanfall.

Ved tre anledninger ble han utredet ved spesialiserte epilepsisentre. Ett døgns 26kanalers langtids-EEG-monitorering ble tatt mens pasienten hadde tre av sine karakteristiske anfall. Monitoreringen viste interiktalt korte grupper av rytmisk 5-6 Hz tetaaktivitet dels med tilspisset karakter temporalt med venstresidig overvekt, noe som ga usikkerhet om det kunne dreie seg om patologiske forhold eller en sjelden fysiologisk variant. Man konkluderte imidlertid med at anfallene var psykogene, og både diazepam og escitalopram ble seponert.

\author{
Grigory Rezvy \\ grigory.rezvy@nlsh.no \\ Voksenpsykiatrisk poliklinikk \\ Nordlandssykehuset \\ Tore Sørlie \\ Institutt for klinisk medisin \\ Universitetet i Troms $\varnothing$ \\ Se kommentar på side 537 \\ Engelsk oversettelse på www.tidsskriftet.no
}


Senere ga ytterligere to nevrologiske utredninger samme resultat. Ved én anledning ble det under et langvarig krampeanfall gitt diazepam $45 \mathrm{mg}$ intramuskulært uten effekt.

Differensialdiagnostikken mellom psykogene, ikke-epileptiske krampeanfall og epilepsi er blitt bedre de siste 30 årene, særlig etter innføring av video-EEG-monitoring (3). Forekomsten av psykogene, ikke-epileptiske krampeanfall i den generelle befolkningen er anslått til ca. 1,5/100 000 per år $(4,5)$ og 25-30\% av alle som henvises til epilepsisentre pga. behandlingsresistent epilepsi får diagnosen $(6,7)$. Mangelfull diagnostikk kan forhindre adekvat kartlegging, bearbeiding og behandling av de underliggende psykososiale årsaksforholdene med forlengelse av lidelse, invalidisering og stigmatisering som resultat. I de tilfeller hvor uvirksom antiepileptisk medikasjon forskrives, kan det også oppstå belastende bivirkninger.

Utredning hos psykiater konkluderte med at pasienten hadde "avhengighets- og konfliktunnvikende trekk», men uten at det ble funnet noe grunnlag for videre utredning/ behandling. Han ble også utredet og behandlet hos privatpraktiserende psykolog, der bruk av tradisjonelle screeninginstrumenter ikke ga holdepunkter for psykisk lidelse. Personlighetstesten Minnesota Multiphasic Personality Inventory (MMPI) (8) avdekket derimot konfliktunnvikende trekk, psykosomatiske reaksjonstendenser, ubevisst fortrenging, forsterket kontroll, aggresjonshemning og redusert selvforståelse. Det ble antatt at pasienten hadde et relativt begrenset mestrings- og reaksjonsrepertoar med tendens til dissosiasjon og psykosomatisk krampereaksjon i belastende situasjoner. Terapien gikk særlig på innsikt i krampeanfallenes personlighetsmessige bakgrunn, utløsende faktorer og hvordan anfall kunne forebygges. Pasienten samarbeidet godt, men behandlingen ga ingen varig bedring $i$ anfallenes frekvens eller alvorlighetsgrad.

Under seks ukers observasjon og utredning i en psykiatrisk avdeling ble flere anfall med bevissthetstap og kramper observert ukentlig. Pasienten ble utskrevet med diagnosen dissosiative krampeanfall ( $F$ 44.5). Han prøvde pregabalin i noen uker, men uten effekt.

De aktuelle plagene medførte stadig økende sykmeldingshyppighet og til sist uføretrygd, 14 år etter det første anfallet.

Dissosiative krampeanfall kan, i henhold til ICD-10, «ligne epileptiske anfall med hensyn til bevegelser, men tungebiting, alvorlige blåmerker eller fall og urininkontinens forekommer sjelden. Det foreligger heller ikke bevisstløshet, men man kan se stuporeller transetilstander» (9).

Etter at pasienten over tid, tilsynelatende uten grunn, hadde rapportert økende tendens til depressivitet og irritabilitet, særlig forut for anfall, henviste fastlegen ham på nytt til et distriktspsykiatrisk senter med ønske om «psykologisk hjelp til takling av situasjoner når hans krampeanfall oppstår». Overfor psykiateren beskrev pasienten seg selv som en veldig energisk og emosjonelt ustabil person med irritabilitet og overdrevne emosjonelle reaksjoner på små hendelser. Han oppga problemer med å holde seg i ro, særlig når han følte seg engasjert, og kunne $i$ perioder før han ble uføretrygdet jobbe mer enn 12-14 timer i døgnet, med lite søvnbehov 13-4 timer per døgn) eller slitenhetsfølelse. Diagnostisk ble det funnet holdepunkter for bipolar lidelse type II, og pasienten takket ja til behandling med lamotrigin. Preparatet ble trappet opp på vanlig måte til en døgndose på $200 \mathrm{mg}$.

Ifølge flere studier kan bipolare lidelser ofte være underdiagnostiserte i vanlig klinisk praksis, bl.a. grunnet mangel på typiske maniske symptomer $(10,11)$. Symptomer som noe forhøyet stemningsleie, uvanlig irritabilitet og minsket behov for søvn i løpet av minst fire dager kan være nok til å mistenke bipolar lidelse $(10,11)$. Lamotrigin er både brukt som stemningsstabiliserende middel ved bipolare lidelser og som antikonvulsivt middel ved epilepsi. Foreliggende evidens indikerer at bipolare lidelser og epilepsi kan ha enkelte felles biologiske mekanismer $(12,13)$.

Noen uker etter oppstart av behandlingen inntrådte det gradvis en betydelig og stabil bedring i pasientens helsetilstand og livskvalitet. Anfallene ble færre og kortere, pasienten følte seg humørmessig mer stabil, hadde bedre kontroll over følelser og sluttet å føle seg ustø. Noen måneder senere ble døgndosen økt til $300 \mathrm{mg}$. Noen uker etter dette hadde han gjennomsnittlig ett $15 \mathrm{mi}$ nutters anfall hver annen uke. Han var fortsatt mindre irritert og mer stabil i humøret. I en periode opplevde han flere konfliktfulle
RAMME 1

Bodde og medarbeideres femnivås modell for psykologiske faktorer som kan være involvert i psykogene, ikke-epileptiske krampeanfall (14).

a) Psykologiske faktorer som kan forårsake tilstanden, så som seksuelt misbruk og personlighetsforstyrrelser.

b) Sårbarhetsfaktorer som kan predisponere for psykosomatiske reaksjoner, så som dissosiasjonstendens og begrensninger i evne til å regulere stress eller løse konflikter.

c) Modellerende faktorer, så som nære slektninger med liknende symptomer.

d) Utløsende faktorer, så som stress og mellommenneskelig konflikt.

e) Opprettholdende faktorer, så som gevinster i form av oppmerksomhet og omsorg samt unngåelse av mestringsmessige og situasjonsmessige utfordringer.

situasjoner og hadde noen dager med flere anfall, men han var generelt fremdeles mer stabil og rolig. Han beskrev sin livskvalitet som betydelig bedret. Etter konsultasjon med nevrolog ble dosen gradvis økt til $600 \mathrm{mg}$ daglig, og serum-lamotrigin ble målt til $29 \mathrm{mmol} / \mathrm{ml}(10-60 \mathrm{mmol} / \mathrm{ll}$. Anfallene kom etter dette gjennomsnittlig 1-2 ganger per måned og varte 15-20 minutter. Omtrent 2,5 àr etter han begynte med lamotrigin har pasienten anfall med 3-4 ukers mellomrom, er fornøyd med behandlingen, føler seg stabil og angir god livskvalitet.

\section{Diskusjon}

Vår pasient hadde i 15 år vært til gjentatte nevrologiske utredninger både ved nevrologiske avdelinger og spesialiserte epilepsisykehus - alle med konklusjonen psykogene, ikke-epileptiske krampeanfall, men uten forslag til behandling. Han hadde også frem til aktuelle utredning og behandling flere ganger vært utredet psykiatrisk/psykologisk, hvor krampeanfallene ble oppfattet som psykogene (dissosiative) og forenlige med psykogene, ikke-epileptiske krampeanfall. Psykoterapeutiske og medikamentelle tilnærminger hadde ikke vært effektive.

Bodde og medarbeidere (14) skisserer en 
femnivås modell for psykologiske faktorer som kan være involvert i psykogene, ikkeepileptiske krampeanfall (ramme 1). Denne modellen likner på andre modeller som brukes for å forklare somatoforme forstyrrelser. Anvendt på vår pasient, så hadde han a) emosjonell ustabilitet, personlighetsrelaterte defensive tendenser og en bipolar lidelse, b) problemer med å regulere stress i hverdagen, d) klare anfallsutløsende faktorer i form av overarbeid, søvnløshet og støy og e) «fordelen» av at anfallene virker avledende på de følelser og opplevelser som oppsto i de situasjonene som anfallene oppsto i (amnesi). Pasientens psykososiale historie er således vel forenlig med psykogene. ikke-epileptiske krampeanfall.

Den tidligere psykologiske utredningen av vår pasient var grundig, men førte ikke frem til effektiv behandling. Når det i den nevrologiske utredningen bare blir satt søkelys på utelukkelse av epilepsi, blir psykogene, ikke-epileptiske krampeanfall en eksklusjonsdiagnose. En positiv diagnose er nødvendig for at underliggende psykisk lidelse skal kunne erkjennes og behandles. Særlig utfordrende kan det være når ansvaret for ulike aspekter ved et sammensatt problem tillegges ulike fag, som i dette tilfellet nevrologi og psykiatri.

Vanligvis vurderes psykogene, ikke-epileptiske krampeanfall som en tilstand som bør behandles innen psykiatrien (15). Vårt eksempel viser imidlertid at disse pasientene kan bli kasteballer mellom nevrologer og psykiatere i stedet for at spesialitetene samarbeider om utredning og behandling.

I tilslutning til de nevrologiske utredninger ble det også gjort uspesifikke EEG-funn som ikke er forenlig med «rene» psykogene, ikke-epileptiske krampeanfall. Kunne for eksempel de første krampeanfallene som var ledsaget av feber, ha forårsaket hjerneskade som ikke lot seg avdekke gjennom EEG-undersøkelser?

Ut fra stress-sårbarhets-modellen, hvor en $\mathrm{X}$-akse representerer en kontinuerlig sårbarhets- eller organisitetsdimensjon og en $\mathrm{y}$-akse representerer en kontinuerlig stressdimensjon, kan man tenke seg alle kombinasjoner av organisitet og stress (16). I denne sykehistorien kan det virke som om det har vært problematisk å diskutere de mulige implikasjoner av flere mulig patologiske EEG-funn samtidig med opprettholdelsen av diagnosen.

Eksisterende forskning har imidlertid vist at psykogene, ikke-epileptiske krampeanfall ikke på noen måte utelukker samtidig epilepsi. Enkelte studier har vist at opptil $50 \%$ av pasienter med tilstanden også har epilepsi på samme tid eller har hatt $i$ fortid, og at den epileptiske komponenten er sterkt underdiagnostisert (17-19).

Sammenlikningen mellom psykogene, ikke-epileptisk krampeanfall og epilepsi er logisk hvis man tenker på den mest åpenbare kliniske manifestasjonen: krampeanfall. Men hvis man prøver å forstå patogenesen $\mathrm{i}$ et bredere biopsykososialt perspektiv, bør man anvende et bredere differensialdiagnostisk spekter.

Behandlingen med lamotrigin ble startet etter at en ny psykiatrisk utredning konkluderte med at pasientens psykiske plager var forenlig med bipolar lidelse type II. Pasienten hadde da i flere år vært invalidisert av sine krampeanfall.

Sammenhengen mellom epilepsi og bipolare lidelser har vært gjenstand for omfattende diskusjoner, særlig i nevrologiske publikasjoner. I flere studier har man kunnet vise at epilepsi og affektive lidelser har mange felles patofysiologiske trekk (20-24). Stor komorbiditet mellom affektive lidelser, særlig depresjoner (25) og bipolaritet $(26,27)$, og epilepsi, oppdagelsen av flere og flere felles trekk i patogenese og nytte av antiepileptika og antidepressiver blant pasienter innen begge diagnosegrupper (28) tyder på at disse to tilstandene er mer beslektet enn det man hittil har trodd.

Vår kasuistikk, med effekten av lamotrigin, kan indikere at psykogene, ikke-epileptiske krampeanfall bør vurderes i sammenheng både med grunnleggende hjerneorganiske patologiske tilstander, som ikke alltid lar seg avdekke med eksisterende undersøkelsesmetodikk, og med bipolar lidelse. Vår klare anbefaling er at diagnostikk og behandling av pasienter med denne tilstanden krever et nært samarbeid mellom nevrologer og psykiatere.

Pasienten har samtykket til at artikkelen blir publisert.

\section{Grigory Rezvy (f. 1963)}

er ph.d., spesialist i psykiatri og overlege. Han har også bistilling som førsteamanuensis ved forskergruppe psykiatri, Institutt for klinisk medisin, Universitetet i Troms $\varnothing$.

Forfatter har fylt ut ICMJE-skjemaet og oppgir ingen interessekonflikter.

\section{Tore Sørlie (f. 1947)}

er dr.med., spesialist i psykiatri. Han er professor i psykiatri, leder av forskergruppe psykiatri, Institutt for klinisk medisin.

Forfatter har fylt ut ICMJE-skjemaet og oppgir ingen interessekonflikter.

\section{Litteratur}

1. Bråthen G. Alkohol og epilepsi. Tidsskr Nor Lægeforen 2003; 123: 1536-8.

2. Cross JH. Fever and fever-related epilepsies. Epilepsia 2012; 53 (suppl 4): 3-8.

3. Iriarte J, Parra J, Urrestarazu E et al. Controversies in the diagnosis and management of psychogenic pseudoseizures. Epilepsy Behav 2003; 4 $354-9$

4. Sigurdardottir KR, Olafsson E. Incidence of psychogenic seizures in adults: a population-based study in Iceland. Epilepsia 1998; 39: 749-52.

5. Reuber M, Elger CE. Psychogenic nonepileptic seizures: review and update. Epilepsy Behav 2003. 4: $205-16$.
6. Alper K Nonepileptic seizures. Neurol Clin 1994: 12: 153-73

7. Witgert ME, Wheless JW, Breier JI. Frequency of panic symptoms in psychogenic nonepileptic seizures. Epilepsy Behav 2005; 6: 174-8.

8. Butcher JN, Dahlstrom WG, Graham JR et al. The Minnesota Multiphasic Personality Inventory-2 (MMPI-2) Manual for Administration and Scoring Minneapolis, MN: University of Minneapolis Press, 1989.

9. ICD-10 psykiske lidelser og atferdsforstyrrelser Kliniske beskrivelser og diagnostiske retningsLinjer. Oslo: Universitetsforlaget, 1999.

10. Smith DJ, Griffiths E, Kelly M et al. Unrecognised bipolar disorder in primary care patients with depression. Br J Psychiatry 2011; 199: 49-56.

11. Podawiltz A. Diagnosing bipolar disorder: signs and symptoms. J Clin Psychiatry 2012; 73: e06.

12. Singh V, Muzina DJ, Calabrese JR. Anticonvulsants in bipolar disorder. Psychiatr Clin North Am 2005; 28: $301-23$

13. Hatzinger M. [Mood stabilizers]. Ther Umsch 2009; 66: 413-24.

14. Bodde NM, Brooks JL, Baker GA et al. Psychogenic non-epileptic seizures-definition, etiology, treatment and prognostic issues: a critical review. Seizure 2009; 18: 543-53

15. Lund C. Haraldsen I, Lossius Ml et al. Psykogene ikke-epileptiske anfall. Tidsskr Nor Legeforen 2009; 129: 2348-51

16. Zubin J, Spring B. Vulnerability-a new view of schizophrenia. J Abnorm Psychol 1977; 86 103-26.

17. Marchetti RL, Kurcgant D, Gallucci Neto J et al. Evaluating patients with suspected nonepileptic psychogenic seizures. J Neuropsychiatry Clin Neurosci 2009; 21: 292-8.

18. Marchetti RL, Kurcgant D, Gallucci-Neto J et al. Epilepsy in patients with psychogenic non-epileptic seizures. Arq Neuro-Psiquiatr 2010; 68: 168-73.

19. Benbadis SR, Agrawal V, Tatum WO 4th. How many patients with psychogenic nonepileptic seizures also have epilepsy? Neurology 2001; 57: $915-7$.

20. Jobe PC. Affective disorder and epilepsy comorbidity: implications for development of treatments, preventions and diagnostic approaches. Clin EEG Neurosci 2004: 35: 53-68.

21. Amann B, Grunze H. Neurochemical underpinnings in bipolar disorder and epilepsy. Epilepsia 2005; 46 (suppl 4): 26-30.

22. Mazza M, Di Nicola M, Della Marca G et al. Bipolar disorder and epilepsy: a bidirectional relation? Neurobiological underpinnings, current hypotheses, and future research directions. Neuroscientist 2007: 13: 392-404

23. Kanner AM. Mood disorder and epilepsy: a neurobiologic perspective of their relationship. Dialogues Clin Neurosci 2008; 10: 39-45.

24. Mula M, Marotta AE, Monaco F. Epilepsy and bipolar disorders. Expert Rev Neurother 2010; 10: $13-23$

25. Henning O, Nakken KO. Epilepsi og depresjon Tidsskr Nor Legeforen 2011; 131: 1298-301.

26. Ettinger AB, Reed ML, Goldberg JF et al. Prevalence of bipolar symptoms in epilepsy vs other chronic health disorders. Neurology 2005; 65 : 535-40.

27. Mula M, Schmitz B, Jauch R et al. On the prevalence of bipolar disorder in epilepsy. Epilepsy Behav 2008: 13: 658-61.

28. Grunze HC. Anticonvulsants in bipolar disorder J Ment Health 2010; 19: 127-41

Mottatt 13.4. 2012, første revisjon innsendt 6.9. 2012, godkjent 3.12. 2012. Medisinsk redaktør Are Brean. 